\title{
Trianthema portulacastrum (L.): An important traditional herb
}

\author{
Ekta yadav, Pankajkumar Yadav and Amita Verma
}

\begin{abstract}
Trianthema portulacastrum (L.) is a potential traditional herb belongs to Aizoaceae family. It is rapidly growing, much branched, succulent, prostrate and annual terrestrial weed. Traditionally it is used for treatment of various ailments like stomachic, laxative, analgesic, anemia, antiulcer, jaundice and abortifacient etc. Various phytoconstituents like alkaloids, glycosides, tannins, flavonoids, steroids, fat, carbohydrates, $\beta$-sitosterol, stigmasterol and phenolic compounds has been isolated from different plant parts. A range of pharmacological activity have been reported from different plant extracts namely hypoglycemic, hypolipidemic, analgesic, hepatoprotective, anthelmintic, anticancer, diuretic and mosquito larvicidal activity etc. The present paper deals with review of traditional uses, phytoconstituents and pharmacological action of plant T. portulacastrum (L.).
\end{abstract}

Key words : Aizoaceae, Phytoconstituents, Ailments, Pharmacological activity

How to cite this paper : Yadav, Ekta, Yadav, Pankajkumar and Verma, Amita (2016). Trianthema portulacastrum (L.): An important traditional herb. Ann. Pharm. \& Pharm. Sci., 7 (1) : 46-52.

Article chronicle : Received : 10.02.2015; Accepted : 28.03.2016

Address for correspondence :

EKTA YADAV,Department of Pharmaceutical Science, Sam Higginbottom Institute of Technology and Sciences, ALLAHABAD (U.P.) INDIA

Email: hiwalekta@gmail.com

Coopted auhors :

PANKAJKUMAR YADAV AND AMITA VERMA, Department of Pharmaceutical Science, Sam Higginbottom Institute of Technology and Sciences, ALLAHABAD (U.P.) INDIA 